\title{
Shiga toxin-producing Escherichia coli in human, cattle, and foods. Strategies for detection and control
}

\author{
Nora L. Padola* and Analía I. Etcheverría \\ Animal Health and Preventive Medicine, Inmunochemistry and Biotechnology, CIVETAN-CONICET-CICPBA-Faculty of Veterinary Sciences- Universidad Nacional del \\ Centro de la Provincia de Buenos Aires, Tandil, Buenos Aires, Argentina \\ ${ }^{*}$ Correspondence: nlpadola@vet.unicen.edu.ar \\ Edited and reviewed by: \\ Yousef Abu Kwaik, University of Louisville School of Medicine, USA
}

Keywords: STEC, cattle, food, environment, virulence factors

Shiga toxin-producing E. coli (STEC) also known as "verocytotoxin-producing E. coli," refers to E. coli pathotypes capable of producing Shiga toxin type 1 (Stx1), type 2 (Stx2), or both, encoded by stx 1 and stx 2 genes, respectively (Paton and Paton, 1998). The genes encoding Stx are carried by temperate bacteriophages insert into bacterial genoma so that Stx production is linked to the induction of the phage lytic cycle (O'Loughlin and Robins-Browne, 2001). STx2 is the toxin type most related to hemolytic uremic syndrome (HUS) and comprise several subtypes which differ in their citotoxicity (Persson et al., 2007). Stx2g is one of those subtypes that were studied by Granobles Velandia et al. (2012) who found several differences among stx $2 \mathrm{~g}$-positive strains. The strains with the highest cytotoxic titer showed higher levels of stx2-phages and toxin production by EIA, while the opposite occured for strains that previously showed low cytotoxic titers, confirming that in st $x 2 \mathrm{~g}$-positive strains Stx production is phage regulated.

Other typical virulence factor is intimin, which is required for intimate bacterial adhesion to epithelial cells inducing a characteristic lesion defined as "attaching and effacing" (A/E). It is encoded by eae gene that presents heterogeneity in their $3^{\prime}$ end and involved in binding to the enterocytes (Guth et al., 2010). Additional virulence-associated markers are a plasmid-encoded enterohemolysin and, in strains lacking eae, an autoagglutinating adhesin (Saa) which could be involved in the adhesion of strains (Paton et al., 2001). Strains laking eae are named as LEE-negative STEC. Steyert et al. (2012) demonstrate that the overall genome content, phage location, and combination of potential virulence factors are variable in this strains group.

STEC are zoonotic pathogens that cause the vascular endothelial damage observed in patients with hemorrhagic colitis (HC) and HUS. HUS is characterized by acute renal failure, thrombocytopenia, and microangiopathic hemolytic anemia and is a potentially fatal cause of acute renal failure in children (Etcheverría and Padola, 2013). HUS there has not treatment and use of antimicrobial agents is associated with an increased risk of severe sequelae such as HUS. Referred to this, Rahal et al. (2012) dicussed novel modalities and regimen of antimicrobial agent administration in an attempt at decreasing their association with aggravating infection outcomes.
Cattle are the main reservoir of STEC and shed the bacteria through their feces spreading these pathogens among cattle herds and the environment. Nguyen and Sperandio (2012) review about the factors and mechanism utilized by O157:H7 STEC for its survival through the acidic environment of the distal stomach and for its colonization in the recto-anal junction. Fernández et al. (2013) characterized two most prevalent serotypes in argentinian cattle demonstrating the potential pathogenic of this strains. Blanco Crivelli et al. (2012) informed that synanthropic species could play role in the transmissibility of the agent thus being a risk to the susceptible population.

Food, water, milk, and person to person contact commonly participate in transmission, although there is a growing concern about some sporadic cases and outbreaks attributable to direct contact with the animal environment (Duffy, 2003). Brusa et al. (2013) report the prevalence of STEC O157 and non-O157 in commercial ground beef and ambient samples, including meat table, knife, meat mincing machine, and manipulator hands suggesting cross-contamination between meat and the environment. One method for reducing STEC in food could be the use of phages. About this, Tomat et al. (2013) inform the isolation of phages highly specific for virotypes of $E$. coli that could be useful in reducing STEC in meat products.

In order to diagnose STEC (O157 and non-O157) several methods have been implemented in the last years (Padola, 2014). Botkin et al. (2012) investigate a multiplex PCR to differentiate EPEC, STEC, and EHEC strains from other pathogenic E. coli, Fratamico and Bagi (2012) use a GeneDisc system to evaluate a new PCR-real time technology based on simultaneous detection of multiple targets, Quiñones et al. (2012) evaluate a DNA microarray targeted 12 virulence factors implicated in produce human disease while Parma et al. (2012) developed a sandwich ELISA for determination of Stx using anti-Stx2 B subunit antibodies showing that could be used in routine diagnosis as a rapid, specific and economic method for detection of STEC. The implementation of Multiple-locus variable-number tandem repeat analysis (MLVA) as subtyping method is review by Bustamante et al. (2012) who have adapted this method for analysis of non-O157 STEC performing an efficient O157:H7 and non-O157 STEC subtyping. 


\section{REFERENCES}

Blanco Crivelli, X., Rumi, M. V., Carfagnini, J. C., Degregorio, O., and Bentancor, A. (2012). Synanthropic rodents as possible reservoirs of shigatoxigenic Escherichia coli strains. Front. Cell. Infect. Microbiol. 2:134. doi: 10.3389/fcimb.2012. 00134

Botkin, D. J., Galli, L., Sankarapani, V., Soler, M., Rivas, M., and Torres, A. G. (2012). Development of a multiplex PCR assay for detection of Shiga toxinproducing Escherichia coli, enterohemorrhagic E. coli, and enteropathogenic E. coli strains. Front. Cell. Inf. Microbio. 2:8. doi: 10.3389/fcimb.2012.00008

Brusa, V., Aliverti, V., Aliverti, F., Ortega Eneas, E., de la Torre, J. H., Linares, L. H., et al. (2013). Shiga toxin-producing Escherichia coli in beef retail markets from Argentina. Front. Cell. Infect. Microbiol. 2:171. doi: 10.3389/fcimb.2012.00171

Bustamante, A. V., Sanso, A. M., Parma, A. E., and Lucchesi, P. M. A. (2012). Subtyping of STEC by MLVA in Argentina. Front. Cell. Inf. Microbio. 2:111. doi: $10.3389 /$ fcimb. 2012.00111

Duffy, G. (2003). Verocytotoxigenic Escherichia coli in animal faeces, manures and slurries. J. Appl. Microbiol. 94, 94S-103S. doi: 10.1046/j.1365-2672.94.s1.11.x

Etcheverría, A., and Padola, N. L. (2013). Shiga toxin-producing Escherichia coli: factors involves in virulence and cattle colonization. Virulence 4, 366-372. doi: 10.4161/viru. 24642

Fernández, D., Krüger, A., Polifroni, R., Bustamante, A., Sanso, A. M., Etcheverría, A. I., et al. (2013). Characterization of Shiga toxin-producing Escherichia coli O130:H11 and O178:H19 isolated from dairy cows. Front. Cell. Infect. Microbiol. 3:9. doi: 10.3389/fcimb.2013.00009

Fratamico, P., and Bagi, L. K. (2012). Detection of Shiga toxin-producing Escherichia coli in ground beef using the genedisc Real-Time PCR system. Front. Cell. Infect. Microbiol. 2:152. doi: 10.3389/fcimb.2012.00152

Granobles Velandia, C. V., Krüger, A., Parma, Y. R., Parma, A. E., and Lucchesi, P. M. A. (2012). Differences in Shiga toxin and phage production among stx2g-positive STEC strains. Front. Cell. Infect. Microbiol. 2:82. doi: 10.3389/fcimb. 2012.00082

Guth, B. E. C., Prado, V., and Rivas, M. (2010). "Shiga toxin-producing Escherichia coli," in Pathogenic Escherichia coli in Latin America, ed A. G. Torres (Washington, DC: Bentham Science Publishers Ltd.), 65-83.

O'Loughlin, E. V., and Robins-Browne, R. M. (2001). Effect of Shiga toxin and Shiga-like toxins on eukaryotic cells. Microbes Infect. 3, 493-507. doi: 10.1016/ S1286-4579(01)01405-8

Padola, N. L. (2014). Advances in detection methods for Shiga toxin-producing Escherichia coli (STEC). Front. Microbiol. 5:277. doi: 10.3389/fmicb.2014.00277

Parma, Y. R., Chacana, P. A., Lucchesi, P. M. A., Roge, A., Granobles Velandia, C. V., Krüger, A., et al. (2012). Detection of Shiga toxin-producing Escherichia coli by sandwich enzyme-linked immunosorbent assay using chicken egg yolk IgY antibodies. Front. Cell. Infect. Microbiol. 2:84. doi: 10.3389/fcimb.2012.00084

Paton, A. W., Srimanote, P., Woodrow, M. C., and Paton, J. C. (2001). Characterization of Saa, a novel autoagglutinating adhesin produced by locus of enterocyte effacementnegative Shiga-toxigenic Escherichia coli strains that are virulent for humans. Infect. Immun. 69, 6999-7009. doi: 10.1128/IAI.69.11. 6999-7009.2001

Paton, J. C., and Paton, A. W. (1998). Pathogenesis and diagnosis of Shiga toxinproducing Escherichia coli infections. Clin. Microbiol. Rev. 11, 450-479.

Persson, S., Olsen, K. E. P., Ethelberg, S., and Scheutz, F. (2007). Subtyping method for Escherichia coli Shiga toxin (verocytotoxin) 2 variants and correlations to clinical manifestations. J. Clin. Microbiol. 45, 2020-2024. doi: 10.1128/JCM.02591-06

Quiñones, B., Swimley, M. S., Narm, K.-E., Patel, R. N., Cooley, M. B., and Mandrell, R. E. (2012). O-antigen and virulence profiling of Shiga toxinproducing Escherichia coli by a rapid and cost-effective DNA microarray colorimetric method. Front. Cell. Inf. Microbio. 2:61. doi: 10.3389/fcimb.2012. 00061

Rahal, E. A., Kazzi, N., Nassar, F. J., and Matar, G. M. (2012). Escherichia coli O157:H7-Clinical aspects and novel treatment approaches. Front. Cell. Infect. Microbiol. 2:138. doi: 10.3389/fcimb.2012.00138

Nguyen, Y., and Sperandio, V. (2012). Enterohemorrhagic E. coli (EHEC) pathogenesis. Front. Cell. Infect. Microbiol. 2:90. doi: 10.3389/fcimb.2012. 00090

Steyert, S. R., Sahl, J. W., Fraser, C. M., Teel, L. D., Scheutz, F., and Rasko, D. A. (2012). Comparative genomics and stx phage characterization of LEE-negative Shiga toxin-producing Escherichia coli. Front. Cell. Infect. Microbiol. 2:133. doi: 10.3389/fcimb. 2012.00133

Tomat, D., Migliore, L., Aquili, V., Quiberoni, A., and Balagué, C. (2013). Phage biocontrol of enteropathogenic and shiga toxin-producing Escherichia coli in meat products. Front. Cell. Infect. Microbiol. 3:20. doi: $10.3389 /$ fcimb. 2013.00020

Conflict of Interest Statement: The authors declare that the research was conducted in the absence of any commercial or financial relationships that could be construed as a potential conflict of interest.

Received: 11 June 2014; accepted: 12 June 2014; published online: 02 July 2014. Citation: Padola NL and Etcheverría AI (2014) Shiga toxin-producing Escherichia coli in human, cattle, and foods. Strategies for detection and control. Front. Cell. Infect. Microbiol. 4:89. doi: 10.3389/fcimb.2014.00089

This article was submitted to the journal Frontiers in Cellular and Infection Microbiology.

Copyright (C) 2014 Padola and Etcheverría. This is an open-access article distributed under the terms of the Creative Commons Attribution License (CC BY). The use, distribution or reproduction in other forums is permitted, provided the original author(s) or licensor are credited and that the original publication in this journal is cited, in accordance with accepted academic practice. No use, distribution or reproduction is permitted which does not comply with these terms. 